\title{
PENGARUH PERGERAKAN BI RATE TERHADAP PERTUMBUHAN DANA PIHAK KETIGA BANK SYARIAH
}

\author{
Oleh : \\ Mimin Widaningsih \\ (Dosen Program Studi Akuntansi Fakultas Pendidikan Ekonomi \& Bisnis UPI BHMN Bandung) \\ Risma Ratna Senjaya \\ (Alumni Program Studi Akuntansi Fakultas Pendidikan Ekonomi \& Bisnis UPI BHMN Bandung)
}

\begin{abstract}
Abstrak
Belum tercapainya pangsa bank syariah sesuai dengan proyeksi yang telah dibuat memberikan pertanyaan tersendiri dalam usaha pengembangan bank syariah. Mengingat potensi besar Indonesia dengan penduduk mayoritas muslim, apalagi sejauh ini peranan bank syariah selalu dinilai baik, salah satu indikatornya tingkat FDR rata-rata yang mendekati $100 \%$. Salah satu faktor penting dalam pencapaian pangsa tersebut adalah jumlah dana pihak ketiga yang dihimpun oleh bank syariah. Banyak bank syariah yang menyatakan bahwa DPK bank tersebut tertekan oleh suku bunga bank konvensional akibat pergerakan BI Rate yang menjadi suku bunga acuan bagi dunia perbankan. Berdasarkan masalah penelitian tersebut, maka dilakukan penelitian terhadap dana pihak ketiga bank syariah secara nasional (BUS dan UUS). Variabel independen dalam penelitian ini adalah $B I$ Rate dan DPK bank syariah sebagai variabel dependen. Sampel yang digunakan adalah DPK bulanan bank syariah secara nasional periode 2006-2008. Metode penelitian yang digunakan dalam penelitian ini adalah metode deskriptif analitis, dan analisis data menggunakan koefisien korelasi product moment dan koefisien determinasi. Hasil penelitian menunjukkan bahwa pergerakan BI Rate cenderung menurun setiap bulannya sedangkan DPK bank syariah cenderung tumbuh naik. Dari hasil penelitian ini dapat diketahui bahwa BI Rate berpengaruh negatif terhadap pertumbuhan DPK bank syariah dengan besar pengaruh sebesar $15,05 \%$.
\end{abstract}

Kata kunci : BI Rate, DPK bank syariah.

\section{Latar Belakang Penelitian}

Bank syariah di Indonesia telah hadir sejak lebih dari lima belas tahun, yakni diawali dengan didirikannya bank Muamalat pada tahun 1992 dan terus berkembang sampai saat ini. Hingga sampai pada Januari 2009, statistik BI menunjukkan bahwa telah terdapat lima Bank Umum Syariah dan 26 Unit Usaha Syariah. Tentunya dalam perjalanannya, bank syariah harus melalui tantangan dan peluang-peluang yang harus dihadapi guna mencapai target tingkat pertumbuhan yang telah ditetapkan, terutama berkaitan dengan kondisi internal dan eksternal dari bank syariah. Maka peluang dan tantangan tersebut akan sangat berpengaruh terhadap kinerja dan pertumbuhan bank syariah itu sendiri.

Berkaitan dengan peluang dan tantangan yang dihadapi oleh bank syariah, jika ditinjau dari fakta pertumbuhan bank syariah yang tidak mencapai proyeksi yang telah 
ditargetkan, memberikan pertanyaan tersendiri dalam pengembangan perbankan syariah. Mengingat potensi penduduk Indonesia yang sangat besar karena Indonesia merupakan negara yang memiliki penduduk Muslim terbesar di dunia, yaitu sekitar 207 juta atau sekitar $88 \%$ dari total jumlah penduduk pada tahun 2007. Apalgi kinerja bank. syariah selama ini selalu dinilai baik salah satunya dilihat dari FDR bank syariah ratarata yang mendekati $100 \%$. Namun, perbankan syariah di Indonesia masih belum mampu menjadi pilihan utama umat Islam di Indonesia. Beberapa fakta yang dapat menggambarkan pertumbuhan perbankan syariah Indonesia selama ini, yaitu pada tahun 2005, pangsa perbankan syariah terhadap perbankan nasional sebesar $1,40 \%$ sedangkan target proyeksi yaitu 1,85\%. Pada tahun 2006 pangsa bank syariah hanya mencapai $1,58 \%$ padahal proyeksi target yaitu sebesar 2,79\%. Pada tahun 2007, Bank Indonesia menetapkan target pencapaian pangsa sebesar 3,94\%. Namun, target tersebut tidak tercapai karena pangsa bank syariah pada tahun 2007 hanya mencapai $1,84 \%$. Begitupun pada tahun 2008, dimana pencapaian pangsa bank syariah hanya sebesar $2,2 \%$, padahal Bank Indonesia menargetkan pangsa bank syariah sebesar $5 \%$.

Jika ditinjau dari segi persaingan, untuk mencapai pertumbuhan yang diinginkannya, sebagai lembaga intermediary yang berfungsi menghimpun dana masyarakat dan menyalurkannya kembali kepada masyarakat, bank syariah tidak hanya berhadapan dengan bank-bank yang ada pada industri perbankan syariah sendiri, tetapi juga harus berhadapan dengan bank-bank konvensional yang menganut konsep bunga sebagai daya tarik. Dimana persaingan tersebut juga sangat dipengaruhi oleh kebijakan Bank Indonesia sebagai pemegang regulasi perbankan di tanah air, Salah satu kebijakan BI tersebut yaitu mengenai bunga acuan BI atau BI Rate. Tingkat suku bunga yang berlaku di dunia usaha maupun tingkat bunga perbankan konvensional mengacu pada tingkat suku bunga Bank Indonesia atau BI Rate.

Bank konvensional dapat lebih fleksibel merespon pergerakan BI Rate dengan menaikkan dan menurunkan suku bunga simpanan dan suku bunga kreditnya. Sementara, bagi bank syariah yang tidak menganut konsep bunga, margin bagi hasil DPK perbankan syariah tidak bisa dinaikkan tanpa didasarkan pada performa penyaluran pembiayaan bagi masyarakat. Akibatnya, ketika seluruh bank konvensional menaikkan suku bunganya akibat kenaikan BI Rate, dapat mengakibatkan nasabah lebih memilih menempatkan dana mereka di bank konvensional.

Menurut Direktur Direktorat Perbankan Syariah BI, Harisman (pasarmuslim.com : 2006), "peningkatan aset disebabkan meningkatnya penghimpunan dana pihak ketiga (DPK)". Jadi, DPK merupakan faktor yang sangat penting dan menentukan dalam upaya mencapai pangsa bank syariah sesuai target yang telah ditetapkan. Jika terdapat masalah pada dana pihak ketiga bank syariah, maka sangat memungkinkan akan berpengaruh pula pada pencapaian pangsa bank syariah.

Peneliti Senior Pusat Pendidikan dan Studi Kebanksentralan Bank Indonesia (BI), Ascarya (Republika : 2007) menyatakan:

Penghimpunan dana pihak ketiga perbankan syariah tertekan perbankan konvensional. Hal itu dipicu oleh kenaikan suku bunga BI (BI Rate) yang Jurnal Akuntansi Riset, Prodi Akuntansi UPI, Vol. 1, No. 2 
mendorong kenaikan suku bunga DPK perbankan konvensional. Sehingga nasabah mengalihkan simpanannya dari bank syariah ke bank konvensional.

Senada dengan pernyataan di atas, Kepala Divisi BII Syariah Chairil A. Azis menyatakan sebagai berikut :

Bank syariah masih bisa berkinerja dengan baik dan mampu bersaing dengan bank konvensional, terutama mengenai bagi hasil jika $B I$ Rate rendah. Namun, jika BI Rate cenderung naik bahkan melebihi 10 persen, bank syariah tidak akan mampu bersaing karena besarnya biaya dana (cost of fund) yang ditanggung. Dengan cost of fund yang tinggi, akan sulit bagi bank syariah untuk bersaing. Sebagai langkah antisipasi, bank syariah akan mengucurkan pembiayaan jangka pendek di mana relatif risiko fluktuasi suku bunganya bisa dibatasi.

Dampak dari kenaikan BI Rate ini dialami pula oleh bank BRI Syariah. Sebagaimana diungkapakan oleh Pemimpin Cabang BRI Syariah Bandung, Sutrisno (Republika:2006) bahwa :

Nasabah yang loyal pada sistem syariah di tempatnya hanya sekitar $20 \%$. Total DPK BRI Syariah hingga Desember 2005 masih mencapai 40 miliar. Namun, pada posisi April 2006 dana masyarakat tinggal 10 miliar. Sisa dana yang lain telah dialihkan pemiliknya ke lembaga konvensional dikarenakan suku bunga dianggap lebih menguntungkan.

Fenomena pengalihan dana tersebut juga terjadi secara nasional sebagaimana diungkapkan Bank Indonesia dalam Laporan Perkembangan Perbankan Syariah tahun 2006 (BI:2006).

Perkembangan DPK perbankan syariah pada tahun 2006 diwarnai kondisi persaingan penghimpunan semakin ketat pada industri perbankan secara umum. Pertumbuhan DPK perbankan syariah mengalami tekanan dalam kondisi suku bunga yang tinggi di awal 2006, namun seiring penurunan suku bunga sejak semester kedua, DPK yang dihimpun perbankan syariah meningkat secara signifikan sehingga mampu mencapai pertumbuhan $32,7 \%$ atau lebih tinggi dari laju pertumbuhan tahun 2005 sebesar $31,4 \%$.

Pada tahun 2007, terdapat fenomena penurunan BI Rate hingga $8 \%$. Hal ini dapat mengakibatkan bagi hasil perbankan syariah semakin kompetitif. Kondisi tersebut dapat mendorong terjadinya perpindahan dana nasabah dari bank konvensional ke bank syariah. Sedangkan pada tahun 2008, BI Rate kembali berfluktuatif, sejumlah kalangan mengkhawatirkan pertumbuhan perbankan syariah Indonesia terancam stagnan atau diam ditempat karena potensi bank syariah untuk menarik dana masyarakat akan menurun akibat tingginya bunga yang ditawarkan bank konvensional yg mengikuti pergerakan BI Rate.

Dari fenomena-fenomena di atas dapat dilihat bagaimana BI Rate mempengaruhi pertumbuhan dana pihak ketiga bank syariah yang pada akhirnya berdampak pula pada Jurnal Akuntansi Riset, Prodi Akuntansi UPI, Vol. 1, No. 2 
pangsa bank syariah terhadap perbankan nasional. Maka, berdasarkan latar belakang yang telah dipaparkan tersebut diatas, peneliti tertarik untuk meneliti mengenai "Pengaruh Pergerakan BI Rate Terhadap Pertumbuhan Dana Pihak Ketiga Bank Syariah".

\section{Rumusan masalah}

1.Bagaimanakah gambaran pergerakan $B I$ Rate.

2.Bagaimanakah gambaran pertumbuhan Dana Pihak Ketiga bank syariah.

3.Bagaimanakah pengaruh BI Rate terhadap pertumbuhan Dana Pihak Ketiga Bank Syariah.

\section{Kerangka Pemikiran}

Perry Warjiyo (2006) menjelaskan bahwa :

Kebijakan moneter juga berdampak pada perbankan dalam hal terjadi perubahan suku bunga, akan meningkatkan risiko pasar dalam neraca bank-bank. Perubahan suku bunga, nilai tukar, dan inflasi akibat pelaksanaan kebijakan moneter akan berpengaruh terhadap kesehatan dan kestabilan perbankan melalui risiko pasar yang terkandung pada kondisi keuangan dan permodalan perbankan. Kebijakan moneter tidak akan efektif apabila perbankan tidak sehat dan stabil karena proses perputaran uang dan mekanisme transmisi kebijakan moneter sebagian besar berlangsung melalui perbankan. Demikian sebaliknya kebijakan perubahan moneter berdampak besar terhadap kondisi kesehatan dan stabilitas perbankan karena perubahan suku bunga, nilai tukar, dan inflasi merupakan tiga elemen penting yang menentukan risiko pasar yang dihadapi perbankan.

Di Indonesia, selaku otoritas moneter, BI memiliki BI Rate sebagai instrumen moneter utama yang digunakan dalam operasi pasar terbuka. Maka, fluktuasi BI Rate sebagai bunga acuan akan diikuti oleh naik turunnya suku bunga pada bank konvensional. Dari uji kausalitas penelitian yang dilakukan oleh Ridho Hakim mengenai struktur pembentukan suku bunga dari sisi perbankan, dapat disimpulkan bahwa secara umum suku bunga SBI mempengaruhi suku bunga penghimpunan dana (tabungan maupun deposito pada bank konvensional).

Bagi bank konvensional, bunga merupakan hal penting untuk menarik minat investor untuk menginvestasikan modalnya pada suatu bank. Semakin tinggi tingkat bunga, para investor akan semakin tertarik untuk menabung. Persaingan antar perbankan konvensional fokus pada keuntungan fungsional. Mereka selalu berlombalomba dalam memberikan keuntungan fungsional agar bisa menjadi pemenang. Sedangkan bank syariah bekerja menggunakan sistem tanpa bunga, tetapi menggunkaan sistem bagi hasil, sehingga keuntungan maupun kerugian ditanggung bersama antara shahibul maal dengan mudharib.

Dalam sistem bunga bank dan bagi hasil mempunyai sisi persamaan, yaitu sama-sama memberikan keuntungan bagi pemilik modal, yang salah satunya adalah masyarakat melalui penghimpunan Dana Pihak Ketiga, yakni berupa giro wadiah, tabungan mudharabah dan deposito mudharabah. Sumber dana ini merupakan sumber dana terpenting bagi kegiatan operasional bank dan merupakan ukuran keberhasilan 
bank jika mampu membiayai operasionalnya dari sumber dana ini. Dana-dana yang dihimpun dari masyarakat merupakan sumber dana terbesar yang paling diandalkan oleh bank (bisa mencapai 80\%- $90 \%$ dari seluruh dana yang dikelola oleh bank). Sehingga bank syariah harus dapat seoptimal mungkin untuk memperoleh dan memanfaatkan dana tersebut.

Fluktuasi BI Rate yang diikuti oleh naik turunnya suku bunga bank konvensional dapat membawa pengaruh pada bank syariah dalam hal kekompetitifan produk-produk bank syariah khususnya dalam kegiatan penghimpunan dana dari masyarakat. Seperti yang telah dijelaskan Karim dalam buku berjudul Bank Islam (2006 : 272), bahwa "bank syariah dalam melaksanakan kegiatan ekonominya harus menghadapi risiko pasar'. Dimana salah satu bagian dari risiko pasar tersebut yaitu risiko tingkat bunga. Risiko tingkat bunga adalah risiko yang timbul sebagai akibat dari fluktuasi tingkat bunga.

Seperti telah dijelaskan sebelumnya bahwa suku bunga konvensional mengacu pada BI Rate. Kepala Divisi Penelitian dan Manajemen Proyek Karim Business Consulting (KBC) Alfi Wijaya (Inilah.com, Januari 2009), menyatakan bahwa :

Perubahan tingkat suku bunga acuan $B I$ Rate akan terlihat pengaruhnya terutama terhadap dana pensiun dan nasabah korporasi besar lainnya. Sedangkan nasabah ritel (kecil) biasanya tidak terlalu sensitif terhadap perubahan tingkat suku bunga.

Nasabah korporasi biasanya memiliki simpanan di atas Rp 500 juta. Sedangkan nasabah di bawah Rp 500 juta termasuk nasabah ritel. Tapi kategori jumlah nasabah itu memiliki kebijakan yang berbeda dengan bank syariah lainnya. Ada juga nasabah $R p$ 100 juta termasuk kategori korporasi.

Azis Budi Setiawan (2006) menjelaskan bahwa dalam kaitan ini, kenaikan $B I$ Rate dan suku bunga penjaminan telah memaksa bank untuk melakukan penyesuaian di kedua sisi neraca. Pada sisi aktiva kenaikan suku bunga kredit berisiko meningkatkan non performance loan (NPL), sementara pada sisi pasiva cost of fund menjadi lebih tinggi terkait dengan upaya bank guna mempertahankan dana masyarakat yang telah dihimpun. Kondisi tersebut (double blows) akan dapat mempengaruhi kinerja perbankan secara signifikan.

Sejalan dengan teori di atas, Diwany (2003) dalam Dadang Romansyah (2009) mengatakan:

Berdasarkan suatu sistem perbankan Islam sekarang, seharusnya jelas bahwa "cost of fund" hilang dari sisi liability dari suatu neraca bank syariah. Jika seorang bankir Islam berbicara mengenai "cost of fund"yang dapat mereka tawarkan, maka kita yakin bahwa mereka belum lepas dari mentalitas riba. Perhitungan cost of fund dengan metode ini menggambarkan bahwa mindset para bankir Islam dalam menjalankan operasional bank syariah tidak berbeda dengan bank konvensional yaitu dengan melakukan perubahan funding rate yang disebabkan ekspektasi akan terjadinya kenaikan cost of fund akibat adanya perubahan struktur biaya untuk mempertahankan nasabah DPK. Akibatnya, perubahan struktur biaya menjadi erat hubungannya dengan adanya perubahan pada variabel sasaran kebijakan moneter, khususnya suku bunga SBI. 
Inti dari teori-teori di atas adalah bagaimana BI Rate mempengaruhi kinerja bank syariah untuk dapat mempertahankan serta menarik dana masyarakat atau Dana Pihak Ketiga Bank Syariah sehingga mengharuskan bank syariah mengambil kebijakankebijkan komprehensif namun tetap harus sesuai dengan aturan syariah. Pada perbankan konvensional tidak ada korelasi yang begitu dekat antara sisi aset maupun liabilitinya. Jika $B I$ Rate naik, maka suku bunganya naik. Sedangkan pada perbankan syariah, seberapa besar keuntungan dana pihak ketiga sangat tergantung pada seberapa besar bank mendapatkan keuntungan dari pembiayaannya. Seperti diungkapkan Adiwarman Karim (Republika, Februari 2009) sebagai berikut :

Kalau di bank syariah, apabila BI menaikkan bunganya maka dampaknya pada bank syariah adalah terhentinya pertumbuhan dana pihak ketiga. Sedangkan di bank konvensional, kalau BI menaikkan suku bunganya, maka yang terjadi adalah mengecilnya margin keuntungan bank konvensional. Jadi, dampaknya beda. Kalau bank konvensional yang kena pukul adalah gross margin-nya sedangkan bank syariah yang kena pukul adalah dana pihak ketiga.

Maka, jika $B I$ Rate naik, produk perbankan syariah menjadi tidak kompetitif karena nasabah lebih memilih menyimpan dananya di bank konvensional yang suku bunganya ikut naik mengikuti kenaikan BI Rate, sehingga dapat mengakibatkan penurunan atau pertumbuhan yang tidak sesuai target pada Dana Pihak Ketiga bank syariah. Namun, ketika BI Rate turun, maka produk bank syariah akan semakin dapat bersaing dan semakin banyak nasabah yang ingin menyimpan dananya di bank syariah. Seperti diungkapkan oleh Pemimpin Kantor Cabang BRI Syariah Makassar, Rusman Saing, bahwa :

Penurunan BI Rate membuat bank-bank syariah lebih menarik bagi nasabah dibandingkan bunga yang ditawarkan bank non syariah. Jadi, kondisi makro ekonomi yang membuat perbankan syariah lebih menarik. Kalau dilihat dari profil nasabah, saat ini memang sudah dominan nasabah rasional. (Fajar Online : 2007).

Beberapa penelitian yang mendukung mengenai pengaruh BI Rate terhadap Dana Pihak Ketiga Bank Syariah yaitu, Pengaruh Tingkat Bunga, Tingkat Inflasi, PDB Perkapita, Dan Bagi Hasil Terhadap Dana Pihak Ketiga (DPK) Bank Syariah Mandiri di Indonesia periode Desember 2002-Desember 2005 oleh Lulu Mazidah. Penelitian tersebut menyatakan bahwa variabel tingkat bunga dan Pendapatan Domestik Bruto (PDB) Perkapita berpengaruh signifikan terhadap penghimpunan Dana Pihak Ketiga Bank Syariah Mandiri, sedangkan variabel tingkat inflasi dan bagi hasil tidak berpengaruh signifikan terhadap penghimpunan Dana Pihak Ketiga Bank Syariah Mandiri.

Sejalan dengan penelitian di atas, penelitian yang dilakukan oleh Ahmad Shonhaji mengenai Analisis Penghimpunan Dana Pihak Ketiga Pada Perbankan Syariah Di Jawa Timur Periode Triwulan II/ 2001- Triwulan III/ 2006 menyatakan bahwa jumlah kantor bank syariah, tingkat bonus SWBI dan tingkat suku bunga, mempunyai pengaruh yang signifikan terhadap penghimpunan DPK pada perbankan syariah Jawa 
Timur. Dari ketiga faktor tersebut jumlah kantor dan tingkat bonus SWBI, mempunyai pengaruh yang positif kecuali tingkat suku bunga SBI.

Maka, bank syariah harus benar-benar memperhatikan pengaruh dari BI Rate tersebut karena dapat mempengaruhi kinerja dan perkembangan bank syariah. Berikut merupakan bagan kerangka pemikiran dari penelitian ini.

\section{Metode Penelitian}

Dalam penelitian ini menggunakan metode deskriptif analitis, yaitu metode yang digunakan untuk menggambarkan data dalam pemecahan masalah dengan mengumpulkan dan menyusun data kemudian menganalisis dan menginterpretasikan data tersebut. Metode penelitian deskriptif digunakan untuk memperoleh gambaran mengenai perkembangan BI Rate dan pertumbuhan dana pihak ketiga bank syariah.

Sehubungan dengan masalah yang diteliti, maka dalam penelitian ini menggunakan desain penelitian kausal. Menurut Husein Umar (2000:62) " desain kausal berguna untuk menganalisis hubungan-hubungan antar satu variabel dengan variabel lainnya atau bagaimana satu variabel mempengaruhi variabel lainnya". Dalam hal ini, jenis desain kausal yang digunakan adalah hubungan asimetris, sesuai dengan sifatnya dimana variabel bebas mempengaruhi variabel terikat. Hal ini karena penelitian ini bertujuan untuk mengetahui pengaruh BI Rate (variabel bebas) terhadap pertumbuhan DPK bank syariah (variabel terikat).

Populasi dari penelitian ini adalah keseluruhan data dana pihak ketiga Perbankan Syariah (BUS dan UUS) secara nasional dari seluruh periode. Dimana sampai pada tahun 2008 terdapat 3 BUS dan 28 UUS. Tiga BUS tersebut yaitu, Bank Muamalat, Bank Syariah Mandiri, dan Bank Syariah Mega Indonesia. Sedangkan 28 UUS terdiri dari Bank IFI, BNI, Bank Jabar, BRI, Bank Danamon, Bank Bukopin, Bank Internasional Indonesia, HSBC, Bank DKI, BPD Riau, BPD Kalsel, Bank CIMB Niaga, BPD Sumatera Utara, BPD Aceh, Bank Permata, Bank Tabungan Negara, BPD Nusa Tenggara Barat, BPD Kalimantan Barat, BPD Sumatera Selatan, BPD Kalimantan Timur, BPD DIY, BPD Sulawesi Selatan, BPD Sumatera Barat, BPD Jawa Timur, Bank Ekspor Indonesia, Bank Lippo, Bank Tabungan Pensiun Nasional, dan BPD Jawa Tengah.

Teknik yang digunakan dalam pengambilan sampel penelitian ini adalah purposive sampling. Adapun sampel yang digunakan adalah data mengenai DPK Perbankan Syariah nasional pada periode 2006-2008. Pemilihan periode 2006-2008 sebagai sampel berdasarkan pada faktor terjadinya fenomena dimana fluktuasi BI Rate yang cukup tinggi terjadi pada periode tersebut dan mengakibatkan adanya persaingan ketat pada dunia perbankan dalam memperoleh dana dari nasabah.

Untuk menguji hipotesis yang peneliti ajukan, diperlukan serangkaian perhitungan dengan cara menganalisis data yang diperoleh. Adapun teknik pengolahan dan analisis data dalam penelitian ini yaitu sebagai berikut : 
1. Menghitung tingkat perkembangan $B I$ Rate per bulan dalam bentuk persentase.

$$
\text { BI Rate bulan (n) - BI Rate bulan (n-1) } \times 100 \% \quad \text { BI Rate bulan (n-1) }
$$

2. Menghitung tingkat pertumbuhan DPK per bulan dalam bentuk persentase.

DPK bulan (n)-DPK bulan (n-1) $\times 100 \%$

DPK bulan (n-1)

\section{- Analisis Statistik}

Berikut merupakan proses dari analisis statistik untuk penelitian ini.

1) "Analisis korelasi product moment digunakan untuk menentukan suatu besaran yang menyatakan bagaimana kuat hubungan satu variabel dengan variabel lain". (Husein Umar : 2000). Analisis korelasi product moment ini digunakan mengetahui seberapa kuat hubungan antara BI Rate dengan tingkat pertumbuhan DPK pada bank syariah. Rumus Product Moment yaitu :

$$
r_{x y}=\frac{n \Sigma X Y-(\Sigma X)(\Sigma Y)}{\sqrt{\left(n \Sigma X^{2}-(\Sigma X)^{2}\right)\left(n \Sigma Y^{2}-(\Sigma Y)^{2}\right)}}
$$

(Husein Umar, 2000: 260)

Dimana $\quad \mathrm{X}=$ tingkat pergerakan $B I$ Rate setiap bulan dalam bentuk persentase

$\mathrm{Y}=$ tingkat pertumbuhan DPK bank syariah per bulan dalam bentuk persentase $\mathrm{n}=$ jumlah data

$r=$ koefisien korelasi product moment

Nilai koefisien korelasi berkisar antara -1 sampai t1, yang kriteria pemanfaatannya dijelaskan sebagai berikut:

a) Jika nilai $r>0$, artinya telah terjadi hubungan yang linier positif, yaitu makin besar nilai variabel $X$ (independen), makin besar pula variabel $Y$ (dependen) atau makin kecil nilai variabel $X$ (independen), maka makin kecil pula variabel $Y$ (dependen).

b) Jika nilai $\mathrm{r}<0$, artinya telah terjadi hubungan yang linier negatif, yaitu makin kecil variabel X (independen), maka makin besar nilai variabel $\mathrm{Y}$ (dependen) atau makin besar nilai variabel $X$ (independen), maka makin kecil pula nilai variabel $Y$ (dependen).

c) Jika nilai $r=0$, artinya tidak ada hubungan sama sekali antara variabel $\mathrm{X}$ (independen) dengan variabel Y (dependen). 
d) Jika nilai $r=1$ atau $r=-1$ telah terjadi hubungan linier sempurna berupa garis lurus. Sedangkan untuk nilai r yang makin mengarah ke angka 0 maka garis makin tidak lurus.

Untuk dapat menginterpretasikan besar kecilnya koefisien korelasi antara variabel independen dan variabel dependen, peneliti menyajikan keeratan hubungan tersebut dalam tabel berikut :

Tabel 3

Keeratan Hubungan Antar Variabel

\begin{tabular}{|c|c|c|}
\hline$r$ & & Tingkat keeratan \\
\hline 0,0 & $0,0 \leq r \leq 0,19$ & Tidak ada korelasi atau sangat lemah \\
\hline 0,2 & $0,2 \leq r \leq 0,39$ & Korelasi lemah tapi berarti \\
\hline 0,4 & $0,4 \leq r \leq 0,59$ & Korelasi sedang yang cukup berarti \\
\hline 0,6 & $0,6 \leq r \leq 0,79$ & Korelasi kuat atau tinggi \\
\hline 0,8 & $0,8 \leq r \leq 1,0$ & Korelasi yang sangat kuat/sempurna \\
\hline
\end{tabular}

(Mudrajad Kuncoro, $2003:$ 44)

2) Koefisien determinasi digunakan untuk menghitung seberapa besar pengaruh $B I$ Rate terhadap tingkat pertumbuhan DPK.

KO $=r^{2} \times 100 \%$

3) Penarikan Kesimpulan. Penarikan kesimpulan diambil berdasarkan hasil pengolahan data dan pengujian hipotesis yang dilakukan berdasarkan kriteria hasil yang dijelaskan di atas, dengan dukungan landasan teori yang diperoleh dari studi kepustakaan yang berhubungan dengan masalah yang diteliti.

Adapun perumusan Ho dan Ha untuk penelitian ini adalah sebagai berikut:

Ho: $\mathrm{r}>0$ : Tidak terdapat pengaruh negatif dari pergerakan BI Rate terhadap pertumbuhan dana pihak ketiga bank syariah

$\mathrm{Ha}: \mathrm{r}<0$ : Terdapat pengaruh negatif dari pergerakan BI Rate terhadap pertumbuhan dana pihak ketiga bank syariah

Gambaran Pergerakan BI Rate

Deskripsi mengenai $B I$ Rate ini ditinjau dari pergerakkan $B I$ Rate setiap bulan, yakni selama tiga puluh enam bulan, dari tahun 2006-2008. Jika melihat data dari tahun 2006-2008, BI Rate mengalami berkali-kali pergerakkan, namun pergerakan tersebut cenderung pergerakan turun. Penurunan tersebut banyak terjadi pada tahun 2006 dan 2007 dimana pada posisi awal 2006, BI Rate berada pada level 12,75\% dan terus menurun sampai akhirnya pada akhir tahun 2007 berada pada level 8\%. Hal tersebut menunjukkan penurunan yang cukup signifikan, walaupun dalam perjalanannya, $B I$ Rate juga sempat mengalami stagnan atau bertahan pada posisi tertentu untuk jangka waktu beberapa bulan. 
Berbeda dengan kondisi tahun 2006 dan 2007 yang diwarnai stagnasi dan penurunan BI Rate, pada tahun 2008 BI Rate mengalami pergerakan yang cukup fluktuatif. Pada awal tahun hingga bulan April, BI Rate tetap bertahan pada posisi $8 \%$. Namun setelah itu, BI Rate mengalami fluktuatif, dimana kenaikan tertinggi pada bulan tersebut membawa BI Rate pada posisi 9,5\% dan pada akhirnya turun kembali pada akhir tahun, yaitu pada posisi $9,25 \%$.

\begin{tabular}{|c|c|c|c|}
\hline Tahun & Bulan & $\begin{array}{l}\text { BI } \\
\text { Rate } \\
(\%)\end{array}$ & $\begin{array}{c}\text { Pergerakan } \\
\text { BI Rate (X) } \\
\text { dalam \% }\end{array}$ \\
\hline \multirow[t]{12}{*}{2006} & 1 & 12.75 & \\
\hline & 2 & 12.75 & 0.000 \\
\hline & 3 & 12.75 & 0.000 \\
\hline & 4 & 12.75 & 0.000 \\
\hline & 5 & 12.5 & -1.961 \\
\hline & 6 & 12.5 & 0.000 \\
\hline & 7 & 12.25 & -2.000 \\
\hline & 8 & 11.75 & -4.082 \\
\hline & 9 & 11.25 & -4.255 \\
\hline & 10 & 10.75 & -4.444 \\
\hline & 11 & 10.25 & -4.651 \\
\hline & 12 & 9.75 & -4.878 \\
\hline \multirow[t]{12}{*}{2007} & 1 & 9.5 & -2.564 \\
\hline & 2 & 9.25 & -2.632 \\
\hline & 3 & 9 & -2.703 \\
\hline & 4 & 9 & 0.000 \\
\hline & 5 & 8.75 & -2.778 \\
\hline & 6 & 8.5 & -2.857 \\
\hline & 7 & 8.25 & -2.941 \\
\hline & 8 & 8.25 & 0.000 \\
\hline & 9 & 8.25 & 0.000 \\
\hline & 10 & 8.25 & 0.000 \\
\hline & 11 & 8.25 & 0.000 \\
\hline & 12 & 8 & -3.030 \\
\hline \multirow[t]{2}{*}{2008} & 1 & 8 & 0.000 \\
\hline & 2 & 8 & 0.000 \\
\hline
\end{tabular}

Jurnal Akuntansi Riset, Prodi Akuntansi UPI, Vol. 1, No. 2 


\begin{tabular}{|r|r|r|r|} 
& 3 & 8 & 0.000 \\
\hline & 4 & 8 & 0.000 \\
\hline & 5 & 8.25 & 3.125 \\
\hline & 6 & 8.5 & 3.030 \\
\hline & 7 & 8.75 & 2.941 \\
\hline & 8 & 9 & 2.857 \\
\hline & 9 & 9.25 & 2.778 \\
\hline & 10 & 9.5 & 2.703 \\
\hline & 11 & 9.5 & 0.000 \\
\hline & 12 & 9.25 & -2.632 \\
\hline
\end{tabular}

Sumber : www.bi.go.id (data diolah)

Jika diperhatikan, penurunan BI Rate biasanya sebesar 25 dan 50 basis poin. Penurunan sebesar 50 basis poin atau sekitar $4 \%$ lebih ini hanya terjadi pada semester dua tahun 2006 dan merupakan penurunan terbesar, dimana pada tahun tersebut pemerintah menetapkan kebijakan moneter cenderung ketat. Sedangkan pada tahuntahun selanjutnya setiap penurunan BI Rate hanya sebesar 25 basis poin atau sekitar $2 \%$ lebih.

Sedangkan untuk kenaikan, setiap kenaikan $B I$ Rate per bulan pada periode 2006-2008 adalah sama yaitu sebesar 25 basis poin atau sekitar 3\%. Kenaikan ini hanya terjadi pada tahun 2008.

Naik turun dan bertahannya suku bunga acuan Bank Indonesia ini guna menyesuaikan dengan kondisi moneter negara. Jika kondisi moneter cenderung membaik, misalnya tingkat inflasi yang rendah dan terkendali, maka BI Rate akan turun. Sedangkan jika kondisi moneter cenderung kurang baik maka Bank Indonesia dapat menaikkan suku bunga seperti terjadi pada tahun 2008 atau mempertahankan suku bunga pada level kebijakan ketat seperti terjadi pada tahun 2006.

\section{Gambaran DPK bank syariah}

Pergerakan dari pertumbuhan DPK bank syariah selama tahun 2006-2008 menunjukkan pergerakkan yang cenderung naik walaupun sempat terjadi penurunan terutama pada tahun 2008 yang mengalami beberapa kali penurunan, namun kenaikan tersebut tetap tidak sesuai dengan target yang telah ditetapkan.

Tabel 4.3

Tabel Pertumbuhan DPK

\begin{tabular}{|r|r|c|r|}
\hline Tahun & Bulan & DPK (Jutaan Rp) & $\begin{array}{c}\text { Pertumbuhan DPK } \\
\text { (Y) dalam \% }\end{array}$ \\
\hline 2006 & 1 & $15,134,968$ & \\
\hline & 2 & $14,872,601$ & -1.734 \\
\hline
\end{tabular}

Jurnal Akuntansi Riset, Prodi Akuntansi UPI, Vol. 1, No. 2 


\begin{tabular}{|r|r|r|r|} 
& 3 & $14,955,706$ & 0.559 \\
\hline & 4 & $15,188,699$ & 1.558 \\
\hline & 5 & $15,834,716$ & 4.253 \\
\hline & 6 & $16,432,728$ & 3.777 \\
\hline & 7 & $16,508,414$ & 0.461 \\
\hline & 8 & $17,107,056$ & 3.626 \\
\hline & 9 & $17,975,508$ & 5.077 \\
\hline & 10 & $18,856,085$ & 4.899 \\
\hline 11 & $19,347,154$ & 2.604 \\
\hline 2007 & 12 & $20,672,181$ & 6.849 \\
\hline & 1 & $20,514,493$ & -0.763 \\
\hline & 2 & $21,054,281$ & 2.631 \\
\hline & 3 & $21,882,933$ & 3.936 \\
\hline & 4 & $22,007,608$ & 0.570 \\
\hline & 5 & $22,570,491$ & 2.558 \\
\hline & 6 & $22,714,256$ & 0.637 \\
\hline & 7 & $23,231,781$ & 2.278 \\
\hline & 8 & $23,308,579$ & 0.331 \\
\hline & 9 & $24,680,417$ & 5.886 \\
\hline & 10 & $25,473,335$ & 3.213 \\
\hline & 11 & $25,658,163$ & 0.726 \\
\hline 12 & $28,011,670$ & 9.173 \\
\hline 1 & $27,695,656$ & -1.128 \\
\hline 2008 & 2 & $29,121,048$ & 5.147 \\
\hline & 3 & $29,552,399$ & 1.481 \\
\hline 4 & $31,063,963$ & 5.115 \\
\hline & 5 & $31,705,310$ & 2.065 \\
\hline 6 & $33,048,523$ & 4.237 \\
\hline & 3 & $32,898,049$ & -0.455 \\
\hline & 8 & $32,358,767$ & -1.639 \\
\hline & $33,568,573$ & 3.739 \\
\hline & 10 & $34,117,748$ & 1.636 \\
\hline & 11 & $34,422,283$ & 0.893 \\
\hline & $36,852,148$ & 7.059 \\
\hline & 5476 & \\
\hline & & & \\
\hline & &
\end{tabular}

Sumber : www.bi.go.id (data diolah) 
Pertumbuhan DPK bank syariah per bulan pada tahun 2006, 2007, dan 2008, masing-masing adalah $2,90 \%, 2,60 \%$ dan $2,56 \%$. Sedangkan untuk pertumbuhan per tahun, masing-masing adalah 32,66\%,35,50\% dan 31,56\%. Pertumbuhan Dana Pihak Ketiga paling tinggi yaitu pada bulan Desember 2007 yaitu 9,17\%. Sedangkan penurunan paling tinggi yaitu terjadi pada bulan Februari 2006 , yaitu sebesar $-1,73 \%$. Sedangkan rata-rata pertumbuhan setiap bulannya dalam periode tiga tahun tersebut yaitu $2,61 \%$.

Komponen terbesar DPK bank syariah yaitu deposito mudharabah, kemudian diikuti oleh tabungan mudharabah dan giro wadiah. Komponen tersebut ditinjau dari besarnya jumlah simpanan, sedangkan dari jumlah rekening atau jumlah nasabah sangat didominasi oleh nasabah tabungan mudharabah.

\section{Pengaruh Pergerakan BI Rate Terhadap DPK Bank Syariah}

Dari perhitungan analisis product moment dapat diketahui bahwa BI Rate dan DPK bank syariah memiliki koefisien korelasi yang negatif. Hal tersebut berarti hipotesis dari penelitian ini diterima, yakni BI Rate memilki pengaruh negatif terhadap pertumbuhan Dana Pihak Ketiga bank syariah. Artinya, ketika BI Rate naik, maka DPK bank syariah akan turun. Dengan koefisien korelasi sebesar $-0,388 \%$ menyatakan bahwa hubungan tersebut merupakan derajat hubungan yang lemah tetapi berarti.

Dari hasil perhitungan koefisien determinasi dapat diketahui bahwa BI Rate mempengaruhi DPK bank syariah senilai $15,05 \%$, artinya pertumbuhan DPK bank syariah dipengaruhi senilai $15,05 \%$ oleh $B I$ Rate dan sisanya dipengaruhi oleh variabel lain yang tidak dijelaskan dalam penelitian ini.

Hasil perhitungan menunjukkan bahwa $B I$ Rate memiliki pengaruh yang tidak begitu besar terhadap pertumbuhan DPK bank syariah. Dari pemaparan di atas dapat disimpulkan mengapa BI Rate tidak berpengaruh besar yakni hanya $15,05 \%$ saja terhadap pertumbuhan bank syariah. Alasan yang dapat dikemukakan mengenai hal tersebut adalah:

1. Ketika BI Rate naik, bank syariah mensiasati hal tersebut dengan meningkatkan nisbah bagi hasil. Kenaikan nisbah bagi hasil tersebut dapat dilakukan oleh bank dengan cara meningkatkan nisbah dari pembiayaan yang diminta bank sehingga keuntungan yang diperoleh bank lebih besar untuk selanjutnya bank juga dapat memberikan return yang lebih besar kepada nasabah pendanaan. Selain mengubah nisbah pembiayaan, bank syariah juga dapat mengubah nisbah pendanaan sehingga porsi untuk nasabah menjadi lebih besar. Hal-hal tersebut telah dilakukan oleh beberapa bank seperti sebagai berikut :

Andi Buchori, Direktur Compliance and Coorporate Support Bank Muamalat (Tempo Interaktif : September 2005) menyatakakan bahwa "jika kondisi memaksa, Bank Muamalat tetap tidak akan mengubah persentase bagi hasil sebesar 8,5 persen. Yang kami ubah nisbah minimal. Persentase nisbah minimal Bank Muamalat adalah $55 \%$ bagi nasabah, dan $45 \%$ bagi bank". 
Sedangkan kebijakan Bank Syariah Mandiri dalam mengahadapi fluktuasi BI Rate adalah seperti yang dipaparkan oleh Direktur Utama Bank Syariah Mandiri Yuslam Fauzi sebagai berikut, "kenaikan patokan BI sudah diantisipasi dengan menaikkan nisbah (rate) pembiayaan, sehingga pendapatan kami naik dan yang dibagi ke deposan juga lebih besar". (Tempo Interaktif : September 2005)

Menurut Direktur Manajemen Resiko Bank Syariah Mandiri Hana Wijaya, Untuk sementara Bank Syariah Mandiri akan menghentikan pembiayaan. Terkait kenaikan Patokan BI sebesar 9,5\%, Bank Syariah Mandiri berniat menaikkan bagi hasil atau mudharabah. BI Rate naik, pasti bank konvesional bunganya juga naik. Kenaikan bagi hasil, agar tidak kalah bersaing dengan bankbank konvensional. (Tempo Interaktif : September 2005)

2. Ketika $B I$ Rate turun, dapat tidak terlalu berpengaruh terhadap kenaikan pertumbuhan DPK bank syariah. Sesuai yang diungkapkan Karim bahwa hal ini dapat diakibatkan karena tertahannya ekspansi pembiayaan dan instrumen penyaluran dana. Kenaikan penghimpunan DPK yang tidak seiring dengan ekspansi pembiayaan akan menyebabkan return yang kecil sehingga tingkat bagi hasil bank syariah menjadi kurang kompetitif.

3. Sering terjadi persaingan suku bunga antar bank konvensional, sehingga penurunan BI Rate kurang atau lambat direspon oleh bank-bank konvensional untuk menurunkan suku bunga pendanaannya, maka secara tidak langsunng berpengaruh pula terhadap kekompetitifan tingkat bagi hasil bank syariah.

4. Sebagian besar dana yang tersimpan di bank syariah adalah berupa deposito, maka pada saat terjadi perubahan pada BI Rate, nasabah tidak bisa langsung memindahkan dananya, karena pada deposito memiliki jangka waktu tertentu.

\section{Simpulan}

Berdasarkan hasil analisis yang telah dilakukan untuk menguji hipotesis dalam penelitian ini, maka dapat ditarik kesimpulan sebagai berikut:

1. Gambaran BI Rate yang dilihat dari persentase pergerakan per bulannya, mulai dari tahun 2006-2008 cenderung mengalami tren penurunan.

2. Gambaran pertumbuhan Dana Pihak Ketiga bank syariah mulai dari tahun 20062008 menunjukkan kecenderungan pertumbuhan yang terus meningkat walaupun pernah beberapa kali mengalami penurunan.

3. BI Rate memiliki pengaruh negatif terhadap pertumbuhan DPK bank syariah.

\section{Saran} ini, yaitu:

Adapun saran yang beberapa saran yang peneliti ajukan berdasarkan penelitin

1. Bank syariah harus mengambil kebijakan-kebijakan komprehensif, misalnya dengan mengeluarkan produk-produk baru yang inovatif untuk menanggulangi masalah pergerakan BI Rate yang berpengaruh terhadap kinerja bank syariah, namun usahausaha itu harus tetap sesuai dengan aturan-aturan syariah sehingga bank syariah 
dapat semakin membuktikan dan aktif mengkomunikasikan bahwa keunggulan prinsip syariahnya tidak hanya memberikan keuntungan dari sisi emosional tetapi juga keunggulan dari sisi finansial yang kompetitif. Jika bank syariah dapat memberikan keuntungan emosional sekaligus finansial, maka nasabah akan semakin banyak dan semakin loyal.

2. Bank syariah harus lebih aktif dalam mempromosikan dan memberikan pemahaman kepada masyarakat mengenai produk-produknya sehingga lebih dikenal di masyarakat dan membuat masyarakat tertarik untuk menjadi nasabah bank syariah. Kegiatan tersebut dapat dilakukan misalnya dengan mengadakan seminar-seminar tentang perbankan syariah.

3. Memperbanyak instrumen penyaluran dana sehingga akan memacu penerimaan dan penggunaan jumlah DPK bank syariah semakin besar.

4. Untuk penelitian selanjutnya, dapat meneliti faktor-faktor lainnya yang mempengaruhi terkendalanya pencapaian pangsa perbankan syariah misalnya dari aspek biaya promosi, jaringan dan efisiensi

\section{Daftar Pustaka}

Abdul Ghofur. (2007). Perbankan Syariah Indonesia. Yoyakarta: Gajah Mada University Press. Adiwarman Karim, (2004). Bank Islam Analisis Fikih dan Keuangan. Jakarta : Rajawali Pers.

Ascarya dan Diana Yumanita. (2005). Strategi Pengembangan LKS di Indonesia. Jakarta: Pusat Pendidikan dan Studi Kebanksentralan Bank Indonesia.

Bank Indonesia. (2003). Bank Sentral Republik Indonesia. Jakarta : Pusat Pendidikan dan Studi Kebanksentralan Bank Indonesia.

Bank Indonesia. (2005-2009). Statistik Perbankan Syariah. Jakarta: Bank Indonesia.

Bank Indonesia. Laporan Publikasi BI Rate jangka waktu 1 bulan. 2005-2009.

Bank Indonesia. (2006). Laporan Perkembangan Perbankan Syariah Tahun 2006. Jakarta : Bank Indonesia.

Heri Sudarsono. (2003). Bank dan Lembaga Keuangan Syariah. Yoyakarta: Ekonisia.

Husaini Usman dan Purnomo Setiady. (1995). Pengantar Statistika. Bandung: Bumi Aksara.

Husein Umar. (2000). Research Methods in Finance and Banking. Jakarta: Gramedia

Karnaen. A Permata dan Hendi Tanjung. (2007). Bank Syariah Teori, Praktik dan Peranamnya. Jakarta: Celestial Publishing.

Kuncoro, Mudarajad. (2003) Metode Riset Untuk Ekonomi dan Bisnis. Jakarta : Erlangga.

Marsuki. (2005). Analisis Sektor Perbankan Moneter dan Keuangan Indonesia. Jakarta: Mitra Wacana Media.

Mohammad Nazir. 1999. Metodelogi Penelitian. Jakarta : Ghalia.

Muhamad. (2002). Bank Syariah. Yoyakarta: UPP AMPYKPN.

Nopirin. (2000). Ekonomi Moneter. Yogyakarta: BPFE.

Nur Indrianto., et.al. (2002). Metodologi Penelitian Bisnis. BPFE, Yoyakarta.

Ridho Hakim, dkk. (2006). Struktur Pembentukan Suku Bunga Dari Sisi Perbankan. Jakarta: Bank Indonesia.

Riduan dan Akdon. (2005). Rumus dan Data Dalam Analisis Statistika. Bandung: Alfabeta.

Rimsky Judiseno. (2002). Sistem Moneter Dan Perbankan Di Indonesia. Jakarta : Gramedia

Jurnal Akuntansi Riset, Prodi Akuntansi UPI, Vol. 1, No. 2 
Rivai, Veitzhal. 2008. Islamic Financial Management. Jakarta : Rajawali Pers.

Siamat, Dahlan. (2004). Manajemen Lembaga Keuangan. Jakarta : Lembaga Penerbit Fakultas Ekonomi Universitas Indonesia.

Sugiyono. 2008. Metode Penelitian Bisnis. Bandung : Alfabeta.

Sururi dan Nugraha. (2007). Belajar SPSS For Windows Untuk mengelola Data Penelitian. Bandung : Dewa Ruchi.

Aziz Budi Setiawan. (2006). Perbankan Syariah: Challenges dan Opportunity. [OnLine]. Tersedia:

http://www.iei.or.id/publicationfiles/Perbankan $\% 20$ Syariah, $\% 20$ Challenges $\% 20$ dan $\% 2$ 0Opportunity\%20Untuk\%20Pengembangan\%20di\%20Indonesia.pdf

Hendra Emerald. (2008). Analisis Risiko Portofolio Dan Pengaruhnya Terhadap Harga Saham Dan Implikasimya Terhadap Nilai Investasi Saham Perkebunan. Tesis. Bandung : SPS UPI.

Hendri Iskandar (2008). Pengaruh Kredit Bermasalah Terhadap Profitabilitas Pada Bank-Bank Go Public. Skripsi. Bandung: FPIPS UPI.

Hidayat, Komarul. (2003). Perbankan Syariah Makin Diminati Masyarakat. Sinar Harapan, 2003.

Karim. Review Special Edition January 2008.

Paina. (2007). Pengaruh karakteristik Keuangan Saham Sektor Perdagangan dan Saham Sektor Properti Terhadap Kinerja Saham. Skripsi. Bandung : FPIPS UPI.

Perry Warjiyo. (2006). "Stabilitas Perbankan Dan Kebijakan Moneter : Keterkaitan Dan Perkembanagannya Di Indonesia". Bulletin Ekonomi Moneter dan Perbankan Maret Vol 8 , Nomor 4 : Bank Indonesia.

Sulastri. (2009). Pengaruh DPK dan NPF Terhadap Volume Pembiayaan Prinsip Bagi Hasil Bank Syariah. Skripsi. Bandung : FPEB UPI.

Adiwarman Azwar Karim. (2008). Bank Syariah Lebih Butuh Likuiditas. [OnLine]. Tersedia: http://www.inilah.com/berita/2008/10/22/56543/bank-syariah-lebih-butuh-likuiditas/

Ahmad Shonhaji. (2007). Analisis Penghimpunan Dana Pihak Ketiga Pada Perbankan Syariah

Di Jowa Timur Periode Triwulan II/ 2001- Triwulan III/ 2006. [OnLine]. Tersedia:

http:/www.adln.lib.unair.ac.id/go.php?id=gdlhub-gdl-s1-2007-shonhajiac5573\&PHPSESSID=caf1 80ece 5b04a7bb38bead $18988 \mathrm{c} 5 \mathrm{~d} 8$

Dadang Romansyah. (2009). Penentuan Rate Bagi Hasil Deposito Mudharabah Bank Syariah D Indonesia (Analisis dan Praktik). [OnLine]. Tersedia:

http://www.ekonomisyariah.org/download/artikel/Dadang\%20Romansyah\%20\%20Penentuan\%20Rate\%20Bagi\%20hasil\%20PPT.pdf

Eko Napiansyah, (2008). BI Rate Tinggi, Bank Syariah Terancam Stagnan. [Online].Tersedia: http://www.tempointeractive.com/hg/ekbis/2008/07/02/brk,20080702-127321,id.html.

Forum Studi Ekonomi Islam. (2009). Sejarah Perkembangan Industri Perbankan Syariah di Indonesia. [OnLine]. Tersedia: http://bumipetani09.blogspot.com/2009/05/perkembangan-sistem-bank-syariah-di.html

Lulu Mazidah. (2008). Pengaruh Tingkat Bunga, Tingkat Inflasi, PDB Perkapita, Dan Bagi Hasil Terhadap Dana Pihak Ketiga (DPK) Bank Syariah Mandiri di Indonesia periode Desember 2002-Desember 2005. [OnLine]. Tersedia:

http://www.adln.lib.unair.ac.id/go.php?id=gdlhub-gdl-sl-2008mazidahlul8750\&PHPSESSID $=$ cafl 80 ece 5 b04a7bb38bead $18988 \mathrm{c} 5 \mathrm{~d} 8$

Jurnal Akuntansi Riset, Prodi Akuntansi UPI, Vol. 1, No. 2 